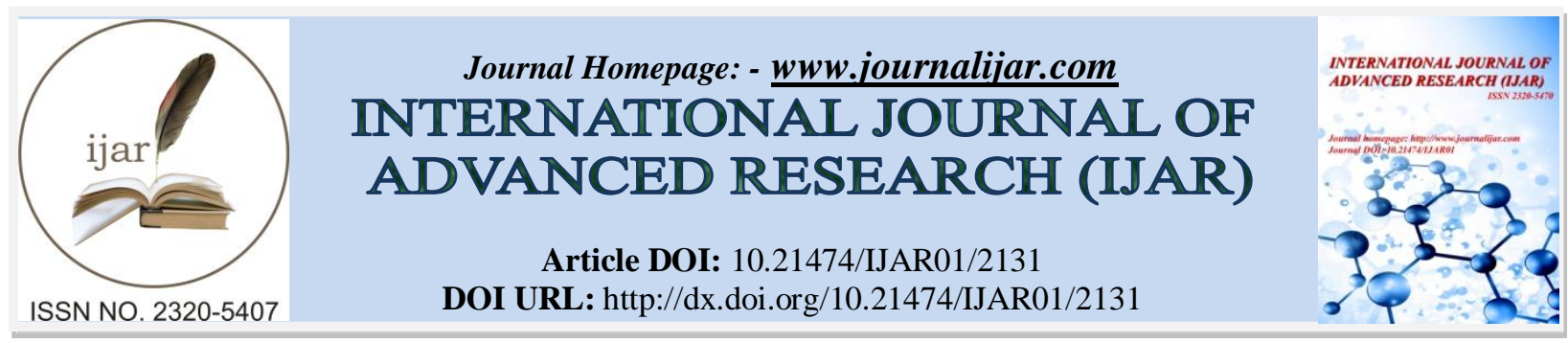

RESEARCH ARTICLE

\title{
GENETIC VARIABILITY, HERITABILITY AND CORRELATION FOR SOME MORPHOLOGICAL CHARACTERS IN 20 DURUM WHEAT ACCESSIONS.
}

Khalid A. M. Hassan and Shihab El deen E. Hassan.

Faculty of Agriculture Natural Resources, Bakht Alruda University, El duim, Sudan.

\section{Manuscript Info}

Manuscript History

Received: 25 September 2016

Final Accepted: 27 October 2016

Published: November 2016

Key words:-

Durum wheat, genetic variability, morphological characters.

\section{Abstract}

Twenty accessions of durum wheat were studied in a randomized block design with four replications. Data on ten characters were recorded. Appreciable variability was displayed by all characters, especially yield/plant and number of grains/plant. Heritability estimates ranged between 47.6 and $89.8 \%$ season 2012 , and 17.8 to $91 \%$ season 2013.

Grain yield/ plant and number of grains /plant were positively and highly correlated with each other and with number spikes/plant, length of master spike, number of spikelet/plant and 1000-grain weight. Number of grains/plant, number spikes/plant and number of spikelet/plant seem to be good morphological criteria of yield.

Copy Right, IJAR, 2016,. All rights reserved.

\section{Introduction:-}

Durum wheat (Triticum durum Desf.) is the second most important Triticum species, next to common wheat (Triticum aestivum L.).

Developing the varieties with high yielding potential having desirable combination of characters is always the main objective of wheat breeding program. The estimation of the genetic association and description of genetic variability between various genotypes are essential for breeders, because the artificial crosses between dissimilar parents permit a huge segregation and the grouping of various favorable alleles (Bered et al., 2002).

The study of character association provides information about the estimates of interrelationship of various yield components in manifestation of yield. Efficiency of selection for higher yield depends upon the knowledge of the trait components and their interaction with grain. This requires information about nature of magnitude of variability in base population and association of yield component with grain yield. Heritability is also a useful technique that estimates the performance of parents in hybrids. Highest heritability in any character shows its highest transmitting ability to next generation (Subhani et al., 2000). Moreover, environment may also relate with the genotypic establishment to effect heritability (Riaz et al., 2003). Low value of genetic advance along with high value of heritability estimates produces an appropriate state for selection. Hence, accessibility of superior knowledge of heritability and genetic advance existing in different yield parameters is a prerequisite for effective plant improvement exercise (Larik et al, 1989). It is also essential to know genetic variability and heritability of important agronomic characters for developing high yielding varieties. It is important to divide total variation in to heritable and non-heritable components with the aid of genetic characters e.g., genotypic and phenotypic coefficient of variation, heritability and genetic advance and genetic association among grain yield and its components for increasing selection (Paul et al., 2006). Association between any two traits or among various traits is of immense 
importance to make desired selection of combination of characters. Correlation analysis provides information about the correlated response plant characters to selection (Ahmad et al., 2003). The correlation coefficient between yield and yield components generally demonstrate a compound sequence of interacting association. The objective of the present study was to estimate genetic variability, heritability and correlation of different characters in durum wheat.

\section{Materials and Methods:-}

Twenty lines of tetraploid species, durum wheat (Triticum durum Desf., $2 \mathrm{n}=4 \mathrm{x}=28, \mathrm{AABB}$ ) originated from various regions in the world were grown in experimental field at the Huazhong Agricultural University, Wuhan, Hubei, China $\left(30 \mathrm{o} 33^{\prime} \mathrm{N}\right)$ over two consecutive cropping seasons (first season 2009-10, second season 2010-11). The experiment was laid out in a randomized block design with four replicates. Each line in a replicate was planted in a row $1 \mathrm{~m}$ along and $20 \mathrm{~cm}$ within rows. Sowing and harvesting for both seasons took place at the end of November and in the first half of June, respectively, field management was the same as field production. Occasional weed control and all other cultural practices were performed according to local practices.

Observations were recorded on ten characters, from randomly selected four plants in each row viz. plant height $(\mathrm{PH})$, spikes/plant (S/P), length of master spike(LMS), neck length of master spike(NLMS), neck of spike-flag leaf pillow Length of master spike (NSFPL)(cm), spikelet/spike(S/S), spikelet/plant (SL/P), grains/plant (G/P), 1000grain weight (TGW) and grain yield/plant (GY/P).

Analysis of variance was carried out by using computer software SAS (Statistical Analysis System). Genotypic coefficient of variation (GCV) and phenotypic coefficient of variation (PCV), heritability in broad sense (H) and genetic advance (GA) as percent of means were estimated by the formula as suggested by Johnson et al (1955). Simple linear correlation coefficient between ten pairs of characters was calculated by using SPSS computer program version 16

Table 1:- Phenotypic Variation in 12 Characters of Durum Wheat Accessions Season 2009-2010

\begin{tabular}{|l|l|l|l|l|l|}
\hline Character & Range & $\begin{array}{l}\text { General } \\
\text { Mean }\end{array}$ & S. E( \pm ) & CV \% & F Value for Lines \\
\hline PH & $92.5-166.0$ & 126.2 & 1.3 & 4.6 & $36.01^{* *}$ \\
\hline S/P & $3.0-10.7$ & 6.6 & 0.5 & 31.1 & $9.67^{* *}$ \\
\hline LMS & $6.0-10.7$ & 9.1 & 0.2 & 11.1 & $11.53^{* *}$ \\
\hline NLMS & $32.2-67.2$ & 46.1 & 1.1 & 9.5 & $16.55^{* *}$ \\
\hline NSFPL & $8.5-32.7$ & 20.3 & 1.0 & 20 & $14.78^{* *}$ \\
\hline S/S & $28.0-18.0$ & 22.6 & 0.4 & 7.5 & $5.41^{* *}$ \\
\hline SL/P & $60.0-225.0$ & 136.1 & 11.1 & 32.6 & $7.26^{* *}$ \\
\hline GY/P & $1.9-7.2$ & 4.3 & 0.6 & 60.1 & $4.65^{* *}$ \\
\hline TGW & $14.5-39.1$ & 21.2 & 1.6 & 30.2 & $5.58^{* *}$ \\
\hline G/P & $114.5-440.7$ & 196.4 & 7.8 & 40.0 & $4.64^{* *}$ \\
\hline
\end{tabular}

Table 2:- Phenotypic Variation in 12 Characters of Durum Wheat Accessions Season 2010-2011

\begin{tabular}{|l|l|l|l|l|l|}
\hline Character & Range & $\begin{array}{l}\text { General } \\
\text { Mean }\end{array}$ & S. E $( \pm)$ & CV \% & F Value for Lines \\
\hline PH & $74.5-157.7$ & 128.1 & 1.6 & 5.1 & $41.78^{* *}$ \\
\hline S/P & $4-8.7$ & 6.2 & 0.48 & 31.5 & $1.86^{*}$ \\
\hline LMS & $7.2-11$ & 8.5 & 0.23 & 11.2 & $4.4^{* *}$ \\
\hline NLMS & $32.7-62.2$ & 51 & 1.1 & 9.2 & $14.0^{* *}$ \\
\hline NSFPL & $10.7-33$ & 24.9 & 0.8 & 13.5 & $14.89^{* *}$ \\
\hline S/S & $19-25$ & 21.7 & 0.45 & 8.3 & $3.56^{* *}$ \\
\hline SL/P & $78.7-191.5$ & 121.1 & 9.9 & 32.8 & $2.1^{*}$ \\
\hline GY/P & $4.7-11.2$ & 7.5 & 0.7 & 37.3 & $1.93^{*}$ \\
\hline TGW & $26.2-51.5$ & 38.4 & 1.3 & 14.2 & $7.08^{* *}$ \\
\hline G/P & $147-329.2$ & 221 & 20.5 & 37.2 & $1.96^{*}$ \\
\hline
\end{tabular}


Table 3:- Phenotypic and genotypic coefficient of variation, components of variance, heritability $(\mathrm{H})$ and genetic advance (GA) of 10 traits of durum wheat Accessions season 2009-2010.

\begin{tabular}{|l|l|l|l|l|l|l|l|}
\hline Character & $\begin{array}{l}P C V \\
(\%)\end{array}$ & $\begin{array}{l}G C V \\
(\%)\end{array}$ & ${ }^{2}{ }_{\mathrm{ph}} \sigma$ & ${ }_{\mathrm{g} \sigma}$ & $\begin{array}{l}{ }_{\mathrm{e}}{ }_{\mathrm{e}} \\
\%\end{array}$ & $\begin{array}{l}\mathrm{HA} \text { as \% of } \\
\text { mean }\end{array}$ \\
\hline PH & 16.1 & 15.2 & 432 & 388 & 44 & 89.8 & 38.5 \\
\hline S/P & 41.4 & 35.2 & 7.25 & 5.25 & 2 & 72.4 & 4.02 \\
\hline LMS & 14.4 & 12.2 & 1.825 & 1.325 & 0.50 & 72.6 & 2.02 \\
\hline NLMS & 19.2 & 17.6 & 87 & 69.2 & 17.80 & 79.5 & 15.2 \\
\hline NSFPL & 38.4 & 33.8 & 61.52 & 47.82 & 13.7 & 77.7 & 12.6 \\
\hline S/S & 10.2 & 7.44 & 6.35 & 3.35 & 3 & 52.7 & 2.73 \\
\hline SL/P & 37.3 & 29.2 & 3180.75 & 1940.75 & 1240 & 61 & 70.8 \\
\hline GY/P & 60.3 & 41.2 & 7.7 & 3.7 & 4 & 48 & 3.55 \\
\hline TGW & 26.1 & 19.1 & 27.7 & 14.8 & 12.9 & 53.4 & 5.79 \\
\hline G/P & 45.8 & 31.6 & 10227.25 & 4873.25 & 5354.2 & 47.6 & 99.0 \\
\hline
\end{tabular}

Table 4:- Phenotypic and genotypic coefficient of variation, components of variance, heritability $(\mathrm{H})$ and genetic advance (GA) of 10 traits of wheat durum accessions season 2010-2011.

\begin{tabular}{|l|l|l|l|l|l|l|l|}
\hline Character & $\begin{array}{l}P C V \\
(\%)\end{array}$ & $\begin{array}{l}\mathrm{GCV} \\
(\%)\end{array}$ & ${ }_{\mathrm{ph} \sigma}$ & ${ }_{\mathrm{g} \sigma} \sigma$ & ${ }_{{ }_{\mathrm{e}} \sigma}$ & $\begin{array}{l}H \\
(\%)\end{array}$ & $\begin{array}{l}\text { GA as \% of } \\
\text { mean }\end{array}$ \\
\hline PH & 17.1 & 16.3 & 479.45 & 436.65 & 42.8 & 91 & 41 \\
\hline S/P & 34.6 & 14.6 & 4.625 & 0.825 & 3.8 & 17.8 & 0.79 \\
\hline LMS & 15.2 & 10.3 & 1.675 & 0.775 & 0.9 & 46.2 & 1.23 \\
\hline NLMS & 19.1 & 16.7 & 95.425 & 73.025 & 22.4 & 76.5 & 15.3 \\
\hline NSFPL & 28.6 & 25.2 & 50.75 & 39.45 & 11.3 & 77.7 & 11.4 \\
\hline S/S & 10.7 & 6.7 & 5.425 & 2.125 & 3.3 & 39.1 & 1.87 \\
\hline SL/P & 37.1 & 17.2 & 2019.6 & 434.375 & 1585.3 & 21.5 & 19.9 \\
\hline GY/P & 41.5 & 18 & 9.725 & 1.825 & 7.9 & 18.7 & 1.2 \\
\hline TGW & 22.5 & 17.5 & 75.2 & 45.4 & 29.8 & 60.3 & 10.7 \\
\hline G/P & 41.5 & 18.2 & 8418.8 & 1631.5 & 6787.3 & 19.3 & 36.6 \\
\hline
\end{tabular}

Table 5:- Correlation coefficients among various pairs of 10 characters in durum wheat accessions first season lower diagonal and second season upper diagonal.

\begin{tabular}{|l|l|l|l|l|l|l|l|l|l|l|}
\hline & PH & S/P & LMS & NLMS & NSFPL & S/S & SL/P & GY/P & TGW & G/P \\
\hline PH & - & -0.02 & 0.05 & $0.72^{* *}$ & $0.73^{* *}$ & 0.21 & 0.007 & -0.01 & 0.20 & -0.09 \\
\hline S/P & -0.07 & - & $0.24^{*}$ & -0.03 & -0.04 & $0.2^{*}$ & $0.9^{* *}$ & $0.7^{* *}$ & -0.004 & $0.85^{* *}$ \\
\hline LMS & -0.06 & $0.38^{* *}$ & - & -0.02 & -0.13 & $0.51^{* *}$ & $0.32^{* *}$ & $0.23^{*}$ & -0.01 & $0.33^{* *}$ \\
\hline NLMS & $0.77^{* *}$ & -0.18 & 0.04 & - & $0.9^{* *}$ & 0.1 & 0.006 & 0.1 & $0.2^{*}$ & -0.01 \\
\hline NSFPL & $0.66^{* *}$ & -0.11 & 0.13 & $0.9^{* *}$ & - & 0.04 & -0.01 & 0.09 & $0.2^{*}$ & -0.02 \\
\hline S/S & 0.21 & $-0.32^{* *}$ & 0.11 & $0.42^{* *}$ & $0.35^{* *}$ & - & $0.44^{* *}$ & $0.40^{* *}$ & -0.13 & $0.41^{* *}$ \\
\hline SL/P & -0.03 & $0.95^{* *}$ & $0.39^{* *}$ & -0.06 & -0.01 & -0.11 & - & $0.78^{* *}$ & -0.08 & $0.88^{* *}$ \\
\hline GY/P & 0.07 & $0.51^{* *}$ & $0.40^{* *}$ & 0.11 & $0.27^{*}$ & -0.05 & $0.55^{* *}$ & - & -.007 & $0.89^{* *}$ \\
\hline TGW & 0.16 & 0.03 & 0.17 & 0.14 & 0.22 & -0.04 & 0.04 & $0.64^{* *}$ & - & -0.15 \\
\hline G/P & 0.07 & $0.60^{* *}$ & $0.41^{* *}$ & 0.12 & $0.28^{*}$ & -0.02 & $0.66^{* *}$ & $0.91^{* *}$ & $0.33^{* *}$ & - \\
\hline
\end{tabular}

\section{Results and Discussion:-}

\section{Genotypic variability:-}

The variability displayed by the ten characters under study is shown in table 1 and 2 . Lines differences in all the characters were significant at $p=0.01$. The highest coefficient of variation (CV) was shown by grain yield/ plant followed by number of grains/plant in both season. Similar CV values were obtained for number of spikelet/plant and number of spike/plant. The least value was shown by plant height and number of spikelet/spike in the first and second season respectively. The variability exhibited by the 20 lines in 10 characters indicates that selection for many of these characters may be effective. However, the characters differed in the extent of their variation as measured by the coefficient of variation. 
The phenotypic and genotypic coefficients of variation ( $P C V$ and $G C V$ ), estimates of the components of variance, heritability and genetic advance are shown in Table 3 and 4.The $P C V$ was generally higher than $G C V$ for all characters, but in many cases the two values differed only slightly. The highest values were shown by grain yield/plant and number of grains/plant in both seasons. Lowest estimate was given by number of spikelet/spike in both seasons.

The heritability estimates ranged between 47.6 and $89.8 \%$ for number grains /plant and plant height, respectively in the first season. While it was ranged between 17.8 and $91 \%$ for number of spikes/plant and plant height in the second season. The heritability estimates for number of grains /plant and number of spikes/plant were lower in magnitude than those for other traits suggests that environmental effects constituted a major portion of the total phenotypic variation. Thus improvement for yield should be based on progeny tests while improvement of the other characters that are highly heritable could be made by selection.

The expected genetic advance, expressed as a percentage of the mean, varied from 2.02 to 99 for length of master spike and number of grain /plant respectively season 2009-2010, and ranged between 0.79 for number of spikes/plant to 41 for the plant height season 2010-2011. Low values were also displayed length of master spike, number of spikes/spike and grain yield/plant in both season. High heritability with low genetic advance as observed in length of master spike and number of spikes/plant indicating the non-additive gene effects. It showed that these characters are largely influenced by environmental effects so selection for improvement of those characters may not be useful. Estimation of genetic advance is useful in knowing the type of gene action in expression of different characters, low values of genetic advance showed non-additive spikelet/spike gene effects so selection of characters with low genetic advance might be ineffective.

\section{Correlation between characters:-}

Grain yield/ plant and number of grains /plant were positively and highly correlated with each other and with number spikes/plant, length of master spike; number of spikelet/plant and 1000-grain weight Table 5. Positive association between grain yield and 1000-grain weight was also reported by, Bahari and Sabzi (2005) and Moral et al.2003. Both characters showed negative and weak correlation with number of spikelet/spike in first season and with plant height in the second season. Number of grains/plant, number spikes/plant and number of spikelet/plant seem to be good morphological criteria of yield.

1000 grain weight correlated negative and not significant with the number of spikelet/spike in both seasons. This adverse correlation seems to be due to the fact that the increase in number spikelet/spike was associated with a reduction in grain size.

Positively and highly significant was observed between plant height, neck length of master spike and neck of spikeflag leaf pillow Length of master spike in both seasons. Although plant height was associated negatively and weak with number of spikes/plant in both seasons.

Number of spikes/plant correlated positively and highly significant with number of spikelet/plant in both seasons. High and positively correlation was observed between neck length of master spike and neck of spike-flag leaf pillow Length of master spike in both season.

\section{Conclusion:-}

The present study indicated that among yield components Number of grains/plant, number spikes/plant and number of spikelet/plan had the highest correlation coefficients with grain yield therefore, may be considered as selection criteria for the improvement of grain yield. 


\section{References:-}

1. Ahmad. M. F., Mohammad. K., Maqbool. A. Azam and S. Iqbal. (2003): Genetic variability and trait correlation in wheat. Sarhad J. Agric., 19(3): 347-35.

2. Bahari. M. and H. Sabzi. (2005): Study of morphological, traits correlation with grain yield of durum wheat. The 8 Iranian Congress of Agronomy and Plant, Gilan.

3. Bered. F. J. Barbosa and F. Carvalho. (2002): Genetic variability in common wheat germplasm on coefficient of percentage. Genetics \& Mol. Biol., 25(2):211-215.

4. Larik, A. S., H. M. I. Hafiz and A. M. Khush. (1989): Estimation of genetic parameters in wheat populations derived from intercultivaral hybridization. Pakphyton, 1:51-56.

5. Moral, G.L., Y. Rharrabit, D. Villegas and C. Roya, (2003): Evaluation of grain yield and its Components in. Durum Wheat under Mediterranean Conditions. An Ontogenic Approach. Agron. J., 95: 266-274.

6. Johanson, H. W., Robinson, H. F. and Comstock, R. E. (1955): Estimates of genetic and environmental variability in Soya bean. Agronomy J., 47(7): 314-315.

7. Paul, A. K., M. A. Islam, M. J. Hassan, M. M. H. Chowdhury. (2006): Genetic variation of some morphophysiological

8. Characters in wheat (Triticum durum L.).Int. J. Sustain. Agric. Tech., 2(8):11-14.

9. Riaz, R., and M.A. Chowdhry. (2003): Estimation of variation and heritability of some physio-morpic traits of wheat under drought condition. Asian. J. Plant. Sci., 2(10):748-755.

10. Subhani, G. M., and M. A. Chowdhry. (2000): Correlation and path coefficient analysis in bread wheat under drought stress and normal conditions. Pak. J. Biol. Sci., 3:72-77. 